\title{
Sustainable development and the social inclusion of disabled people
}

\begin{abstract}
The seventeen Sustainable Development Goals of the 2030 UN Agenda for Sustainable Development were adopted by world leaders at an historic UN Summit in 2015 and officially came into force in 2016. The goals are not legally binding, but it is for every state to build its own sustainable development policies and to report on their implementation in practice. This article aims to analyse the recognition of the rights of disabled people and of social inclusion as an important component of sustainable development. It focuses on the situation in the Republic of Macedonia after its ratification of the UN Convention and explores a couple of the paths which have been adopted to ameliorate the position of disabled people in Macedonia and which assist with the country's responsibility to implement sustainable development goals. The article concludes by identifying several measures focused on legal and practical action that will be necessary to achieve the social inclusion of disabled people and the goals of sustainable development, particularly in the area of social policy and employment.
\end{abstract}

Keywords: Social development, sustainable development, inclusion, disabled people, employment, education

\section{Sustainable Development Goals}

The seventeen Sustainable Development Goals, and 169 targets, which were introduced alongside the United Nations agenda are set as priorities for member states up until 2030. ${ }^{1}$ They seek to build on the Millennium Development Goals and complete what they did not achieve. They seek to realise the human rights of all and to achieve gender equality and the empowerment of all women and girls. The Goals are integrated and indivisible, and balance the three dimensions of sustainable development: the economic; the social; and the environmental (see also the graphic below).

In terms of the aims of this article, the achievement of several of the goals from this agenda represents an absolute priority:

- ending poverty in all its forms everywhere

- ensuring healthy lives and the promotion of the well-being of all, at all ages

- ensuring inclusive and equitable quality education and promoting lifelong learning opportunities for all

- achieving gender equality and the empowerment of all women and girls

1 http://unfoundationblog.org/common-questions-on-the-global-goals/. 
- promoting sustained, inclusive and sustainable economic growth, full and productive employment and decent work for all

- building a resilient infrastructure

- promoting inclusive and sustainable industrialisation and fostering innovation

- promoting peaceful and inclusive societies for sustainable development

- providing access to justice for all

- building effective, accountable and inclusive institutions at all levels. ${ }^{2}$

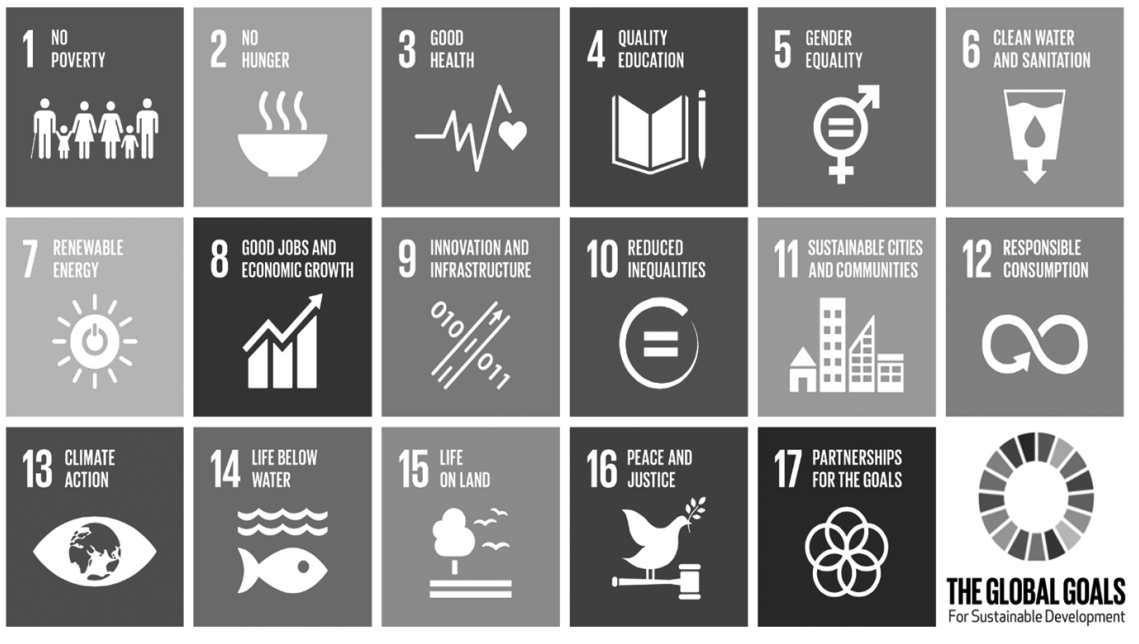

The Millennium Development Goals had been agreed back in 2000 as targets for all UN member states to try and achieve by 2015. These provided an important framework for development, and significant progress was made in a number of areas. Despite the halving of the global poverty rate since 2000, intensified efforts are still required to boost incomes, alleviate suffering and build the resilience of those individuals still living in extreme poverty, in particular in sub-Saharan Africa.

In 2013, an estimated 767 million people lived below the international poverty line of $\$ 1.90$ a day - down from 1.7 billion people in 1999. In 2016, just under 10 per cent of the world's workers were living with their families on less than $\$ 1.90$ per person per day, down from 28 per cent in 2000. In the least developed countries, nearly 38 per cent of workers in 2016 were still living below the poverty line.

In 2016 , only 28 per cent of people with severe disabilities collected disability benefits, only 22 per cent of unemployed individuals worldwide received unemployment benefits and only 41 per cent of women giving birth received maternity benefits. $^{3}$

2 http://www.unfoundation.org/features/globalgoals/the-global-goals.html.

3 Report of the UN Secretary-General (2017) Progress towards the Sustainable Development Goals available at: http://www.un.org/ga/search/view_doc.asp?symbol=E/2017/66\&Lang=E. 
Furthermore, social protection systems need to be expanded and risks need to be mitigated for disaster-prone countries, which also tend to be the most impoverished.

Several developing countries have made great strides in improving the coverage of disabled people, but benefits often remain inadequate. Data for 29 developing countries indicate that the amounts received through tax-financed disability schemes are often less than 15 per cent of per capita GDP. Disability benefits range from 51 per cent of per capita GDP in Uzbekistan and 35 per cent in Brazil to less than 5 per cent in China and India. Significant variations are also found in richer countries: means-tested disability benefits in Singapore range from 3 per cent to 5 per cent of per capita GDP, while those in the Republic of Korea range from 2 per cent to 7 per cent, depending on the severity of the disability and the beneficiary's level of income. $^{4}$

The purpose of this article is to examine the social inclusion of disabled people, particularly in employment, as a way both of eradicating poverty and achieving equality. Ex-Secretary General of the United Nations, Kofi Annan, perhaps expressed it best:

Access to information and communication technologies creates opportunities for all people, perhaps none more so than persons with disabilities. As the development of the Internet and these technologies take their needs more fully into account, the barriers of prejudice, infrastructure and inaccessible formats need no longer stand in the way of participation.

The research question; however, is what more needs to be done to encourage more inclusive societies for vulnerable groups and to facilitate better access to education and employment opportunities.

\section{UN disability regulation}

The biggest step forwards in regulating the human rights of disabled people is the UN Convention on the Rights of Persons with Disabilities (CRPD). By October 2018, there were 161 signatories to the Convention and 177 ratifications/accessions, which includes 172 states and the European Union; while the Optional Protocol currently has 92 signatories and 92 ratifications/accessions.

The Convention has fifty articles and lays down eight guiding principles:

- respect for inherent dignity and individual autonomy, including the freedom to make one's own choices, and independence of disabled people

- non-discrimination

- full and effective participation and inclusion in society

- respect for difference and acceptance of people with disabilities as part of human diversity and humanity

- equality of opportunity

- accessibility

- equality between men and women

4 Development Pathways: Disability Benefits Scheme Database available from: http://www.dev elopmentpathways.co.uk/publications/\#disability-database. 
- respect for the evolving capacities of children with disabilities and respect for the right of children with disabilities to preserve their identities.

The CRPD is the first UN human rights treaty of the $21^{\text {st }}$ century. It adopts a modern social model of disability as a means of explicitly recognising the legal rights of the world's largest marginalised group and, in a break from its predecessor treaties, contains novel provisions for implementation and monitoring based on the establishment of a progressive structure and process for the oversight of human rights. ${ }^{5}$

The Convention identifies two levels of action aimed to achieve its goal:

- prohibiting discrimination based on disability

- establishing an obligation to take proactive measures aimed at creating conditions which are conducive to the effective realisation and enjoyment of all human rights and freedoms by disabled people.

The EU signed the UN Convention on the Rights of Disabled People on its opening day for signature, on 30 March 2007; and it has since been signed by all $28 \mathrm{EU}$ countries. Following completion of the ratification procedure, the EU as a whole became not only the $97^{\text {th }}$ party to the Convention but the first international organisation; ${ }^{6}$ the first time that the European Union had become a party to any international human rights treaty.

The Convention sets out minimum standards for protecting and safeguarding a full range of civil, political, social and economic rights for disabled people. Consequently, it reflects the Union's broader commitment to building a barrier-free Europe by 2020 for the estimated 80 million disabled people living in the EU, as set out in the European Commission's disability strategy. All EU legislation, policies and programmes must comply with the CRPD's established obligations.

In view of its obligations under the Convention, the European Commission has put forward a proposal for a European Accessibility Act. This proposed directive aims to ensure the full participation of disabled people in society and to reduce the fragmentation of legislation governing access to products and services.

The European Union has taken on an important role in setting down minimum standards with respect to disability discrimination law within member states since 2000. With the adoption of the Amsterdam Treaty, Article 13 of the Treaty Establishing the European Communities includes sex, racial or ethnic origin, religion or belief, disability, age or sexual orientation as the basis for forbidding discrimination (now contained in Article 19 of the Treaty on the Functioning of the European Union). This is the legal basis for the adoption of the EU's equal treatment directives, including:

5 Reiss, Jennifer W (2012) 'The Convention on the Rights of Persons with Disabilities in the Post-Lisbon European Union' Human Rights Brief 19(2): 18-23.

6 European Commission MEMO/10/198 on Disability Rights: EU and the Ratification of the UN Convention on the Rights of Persons with Disabilities, available at: http://europa.eu/rapid/ press-release_MEMO-10-198_en.htm. 
- Council Directive 2000/43/EC implementing the principle of equal treatment between persons irrespective of racial or ethnic origin (the 'Race Equality Directive')

- Council Directive 2000/78/EC establishing a general framework for equal treatment in employment and occupation (the 'Equal Treatment Directive')

Furthermore, the Equal Treatment Amendment Directive (2002/73/EC), with its new Article 8(a) obliges member states to create special bodies with promotional, analytical, monitoring and support functions regarding the implementation of the principle of equal treatment. In addition, the EU has funded several research projects on the development of assistive technologies under its research and innovation framework programmes. Assistive technologies in support of disabled people have evolved considerably throughout the broad categories of motor, vision, hearing, cognitive and communications disabilities. They now cover sophisticated ICT, software, cyberphysical and stem-cell applications and include non-invasive and invasive braincomputer interfaces, wearable devices, stem-cell applications, neuro-prosthetics, humanoid robots and applications (apps). ${ }^{7}$

\section{Republic of Macedonia - case study}

The Republic of Macedonia signed the Convention on the Rights of Persons with Disabilities on 30 March 2007 and the Optional Protocol on the 29 July 2009. The Convention delivers a legal framework for the protection and promotion of the rights of disabled people, thus making a major step forward in our understanding of the concept of disability not just as a personal problem but as a social problem facing the country. The countries that have ratified this Convention are legally obliged to treat people with physical and mental disabilities as equal subjects and members of society. In signing and ratifying the Convention, the Republic of Macedonia thus continues on its road to a more inclusive and equal society.

Even so, the country has encountered problems in taking specific steps in implementing the Convention. The area of employment is one of the most crucial spheres in which further efforts are particularly important as regards being more inclusive of disabled people. Article 6 of the Labour Law contains an anti-discrimination clause in the employment field. However, to improve on the situation in the employment of people with a disability, the Republic of Macedonia adopted a special Law on the Employment of Disabled Persons. ${ }^{8}$ Article 2 of this law provides the definition of a person with a disability and extends this to cover the benefits for those employers who engage people with a disability. Article 4 regulates specific measures for improving the working conditions of disabled people, including grants to employers of disabled people, such as financial support for adaptations of the workplace and ap-

7 European Parliament Briefing (2015) Assistive technologies to support people with disabilities June, available at: http://www.europarl.europa.eu/RegData/etudes/BRIE/2015/559513/EP RS_BRI(2015)559513_EN.pdf.

8 Law on the Employment of Disabled Persons (2008) Official Gazette of the Republic of Macedonia No. 144. 
propriate equipment for workers with a disability based on the criteria defined by the statute; as well as tax benefits and financial support in the work process.

In August 2009, the Law on Sign Language was adopted..$^{9}$ The Republic of Macedonia has to improve accessibility for and the education of disabled people in order to include them in employment. In the era of internet connections, the education of the person with a disability must itself be made more accessible.

The National Strategy for Disability Policy 2010-2018 aims to:

- harmonise policies in the area of the protection of the rights of disabled people in line with domestic and international standards

- include trends in the accessibility of people with a disability in all areas of living and working

- continue the development of international standards, including creating the best available model of protection based on the principles of non-discrimination

- improve the domestic legal framework for the protection of disabled people

- take measures for implementing the legislation and monitoring the effectiveness of its implementation.

In 2016, an official survey of non-employed disabled people totalled 1490 people of whom 1007 were men (67.6\%) and 483 were women $(32.4 \%)$. As regards age, $18.7 \%$ were $15-29 ; 52.8 \%$ were aged $30-49$; and $28.5 \%$ were 50 or over. Concerning educational level, $56.4 \%$ had no education while just $19.5 \%$ had secondary legislation and only $3.5 \%$ higher education. ${ }^{10}$

At the proposal of the Ministry of Labour and Social Policy, the government of the Republic of Macedonia adopted its 2018 Programme for Personal Assistance for Disabled people. Such a service was thus introduced for the first time in Macedonia and was fully-financed by the Budget. The programme was intended to provide a level of personal assistance for 100 people aged 18 to 64 who had a severe mental or severe physical disability or who had complete visual impairment. Personal assistants would aid them to carry out everyday personal or domestic activities, visit higher education institutions or engage in non-formal education, occupational therapy or workplace support. The introduction of personal assistants was intended to strengthen the social protection system and contribute to the practical implementation of the UN Convention on the Rights of Persons with Disabilities. The Ministry of Labour and Social Policy was given the task of monitoring the implementation of the programme in order to plan the expansion of the coverage and availability of the service in the next period. The total budget for the programme was $€ 286885$.

\section{Conclusions and future challenges}

Part of the sustainable development goals for 2030 are the reduction of poverty and the creation of equal opportunities and an environment of non-discrimination for everyone in each sphere including education, employment, access to goods and services, social support, etc. In order to have more inclusive societies, international or-

9 Law on Sign Language (2009) Official Gazette of the Republic of Macedonia No. 105.

10 Reported on www.avrm.gov.mk (Employment Service Agency of the Republic of Macedonia). 
ganisations have adopted important legal acts and various initiatives to improve the lives of disabled people. The shadow report produced by the UK Independent Mechanism confirmed in 2017 that:

Disabled people are more likely to live in poverty and material deprivation than people who are not disabled, and continue to be disproportionately affected by a range of social security reforms. ${ }^{11}$

In the context of employment, the report goes on to articulate that:

Disabled people are much less likely to be in employment than non-disabled people. They experience barriers to finding and staying in work, and are on average paid less;

while, within the education system:

Further efforts are needed to achieve an inclusive education system and there are higher exclusion rates and lower attainment rates for disabled pupils. Disabled young people face barriers to transitioning from school to further education or employment.

If we are to get to where we need to be with to improving the social inclusion of disabled people, the taking of additional measures is surely to be required. As a minimum, these would seem to be based on the following several major action points:

- raising awareness and improve the understanding of social inclusion

- bring out new perspectives on the policy approach on disability in participating countries within the framework of the Convention

- generate fresh insights into the activities of governments, the UN system and non-governmental organisations in addressing issues related to disability

- creating and strengthening local and national cross-disability umbrella bodies

- adopting new forms of educational learning methods like on-line courses and non-formal educational programmes adapted to the needs of an open labour market.

\section{References}

Development Pathways: Disability Benefits Scheme Database available from: http:// www.developmentpathways.co.uk/publications/\#disability-database

European Commission MEMO/10/198 on Disability Rights: EU and the Ratification of the UN Convention on the Rights of Persons with Disabilities, available at: http://europa.eu/rapid/press-release_MEMO-10-198_en.htm.

European Parliament Briefing (2015) Assistive technologies to support people with

11 UK Independent Mechanism (2017) Disability Rights in the UK. Updated submission to the UN Committee on the Rights of Persons with Disabilities in advance of the public examination of the UK's implementation of the UN CRPD. Available at: https://www.equalityhumanrights.com/sites/default/files/crpd-shadow-report-august-2017.docx. 
disabilities June, available at: http://www.europarl.europa.eu/RegData/etudes/BRIE/ 2015/559513/EPRS_BRI(2015)559513_EN.pdf.

European Union (2017) European Disability Policy, From defining disability to adopting a strategy.

Kumpuvuori, Jukka and Martin Scheinin (Eds.) (2009) United Nations Convention on the Rights of Persons with Disabilities: Multidisciplinary Perspectives Centre for Human Rights of Persons with Disabilities in Finland (VIKE), VIKE Publications Series No. 5, Helsinki.

Reiss, Jennifer W (2012) 'The Convention on the Rights of Persons with Disabilities in the Post-Lisbon European Union’ Human Rights Brief 19(2): 18-23.

Report of the UN Secretary-General (2017) Progress towards the Sustainable Development Goals available at: http://www.un.org/ga/search/view_doc.asp?symbol=E /2017/66\&Lang=E.

UK Independent Mechanism (2017) Disability Rights in the UK. Updated submission to the UN Committee on the Rights of Persons with Disabilities in advance of the public examination of the UK's implementation of the UN CRPD. Available at: https://www.equalityhumanrights.com/sites/default/files/crpd-shadow-report-a ugust-2017.docx.

Law on the Employment of Disabled Persons (2008) Official Gazette of the Republic of Macedonia No. 144.

Law on Sign Language (2009) Official Gazette of the Republic of Macedonia No. 105.

http://unfoundationblog.org/common-questions-on-the-global-goals/.

http://www.unfoundation.org/features/globalgoals/the-global-goals.html. 